Chapter 4

\title{
Technology as quality work? educational leaders and teachers' use of digital technology
}

Trine Fossland and Cathrine E. Tømte

\begin{abstract}
In January 2017, the Norwegian Ministry of Education and Research launched the white paper 'Culture for Quality in Higher Education', in which they underlined the need for a cultural shift to promote quality in higher education. The white paper outlined five main strategies and a series of actions to enhance institutional 'quality work', and identified the use of digital technology as a key driver to stimulate the provision of innovative teaching and learning processes. Leaders and teachers within Norwegian universities and university colleges are expected to enhance their use of digital technology as part of their quality work. This could include innovative teaching and learning methods and student-centered learning perspectives and practices. However, it appears to be a mismatch between national ambitions and the take-up of digital technology within institutional practices in higher educational institutions. In this chapter, we illuminate this inconsistency through the lenses of translational theory and concepts of 'conflicting logics' and 'translational costs' within higher education institutions. Based on findings from the Quality of Norwegian Higher Education: Pathways, Practices and Performances (QNHE) research project, we analyse how Norwegian higher education institutions have responded to governmental policies on digital technology usage in their quality work.
\end{abstract}

\section{Introduction}

All over Europe, national higher education institutions' (HEIs) policies have outlined the importance of facilitating student-active teaching methods to enhance educational quality. Technology is often considered a means to facilitate this pedagogical shift. The European University Association (EAU) argues that digitalisation represents one of the three most influential challenges within higher education (Sursock, 2015). However, this attention towards digitalisation within HEls is not new. Stensaker and colleagues demonstrated more than ten years ago that in Norway HEIs' response to the 
Bologna process and its ambitions towards student-active teaching and learning processes was to establish overall digitalisation strategies and to stress the importance of technological infrastructure. Their study also addressed the importance of communicating the overall purposes of using digital technology in pedagogical contexts to academic staff (Stensaker, Maassen, Borgan, Oftebro \& Karseth, 2007). Nonetheless, at least in Norway, in recent years we have seen renewed attention towards digitalisation within HEls and the role of technology in supporting and enhancing the pedagogical shift towards student-active teaching methods, which again are often considered a means of quality in education (Lillejord, Børte, Nesje \& Ruud, 2018).

In this chapter, we explore how this renewed attention to digital technology usage is manifested in teachers' and leaders' quality work within HEls in Norway, which we interpret as the 'practices and processes involved in quality enhancement' (Elken \& Stensaker, 2019). Academic leaders and teachers are expected to 'translate' the national ambitions on digital technology use, including certain additional costs. We address the following research question: 'How do institutional leaders and teachers translate the national ambitions of digital technology use in their institutional quality work?' We use empirical data, including institutional strategies and course documents, interviews with diverse leaders with responsibility for educational quality work, and study-programme leaders (survey), as well as observations and interviews with teachers and students from one institutional case study in the Quality of Norwegian Higher Education: Pathways, Practices and Performances (QNHE) research project (Fossland \& Tømte, 2018). Educational leadership, including the function of study-programme leader (henceforth referred to as SPL) in HEls is often found to be difficult to define, as the same positions are constructed in many different ways. ${ }^{1}$ In this chapter, we identify educational leaders as those staff members responsible for a) full-time educational programmes (MA and BA) within public Norwegian universities and university colleges (Aamodt et al., 2016) and b) education within the selected institutions in the QNHE project.

The chapter is organised in five sections. The first introduces Norway's national ambitions on the use of digital technology, while the second presents the theoretical approach to analysing leaders' and teachers' use of digital technology in quality work - that is, within a frame of translation theory and perspectives on competing institutional logics. The third section introduces the methods and data sources that underlie the chapter, while the fourth presents the findings and analysis of quality work related to national ambitions as well as describing the analytical scope. In the fifth and final section,

\footnotetext{
${ }^{1}$ See Aamodt et al. (2016) for a more detailed discussion of the concept and the selection procedure.
} 
we discuss the findings and present the major conclusions of our analyses. By identifying and analysing barriers and the translational costs included in teachers' and leaders' use of technology, we provide possible explanations for why institutional practices in digital technology usage have not developed as expected.

\section{Technology as quality work: National ambitions on technology usage}

Over the last ten years, the Norwegian Ministry of Education and Research has flagged digital technology for enhancing the quality of teaching and learning in higher education. In January 2017, the Ministry issued a white paper titled 'Culture for Quality in Higher Education', which emphasised the need for a cultural shift to promote quality work within higher education in Norway (Norwegian Ministry of Education and Research, 2017). This white paper underlines a need to strengthen digital competences, academic leadership, as well as institutional and national support structures in order to realise the potentials of digitalisation. The hite paper states that "digital technology has a potential to create new conditions for teaching and learning, ways of organising content and new forms of communication and organisation" (p. 12), at the same time indicating that "academic staff are not anchoring the use of digital tools in curricula, subject descriptions and work requirements" (p. 51). Five main strategies and a series of actions towards realising those strategies are outlined in the paper. The Ministry wants to promote (1) ambitions on behalf of students, (2) active and varied learning activities, (3) a 'quality culture', (4) clear education management, and (5) closer integration and interaction with workplaces. The transformative aspects of these five strategies are obvious, such as using digital tools to create more active and varied learning activities, implementing new ways of sharing, communicating, and collaborating over distances, and using multimodal expressions in diverse ways (Fossland, 2015).

The Ministry produces an annual status report on Norwegian higher education, wich in 2018 clearly stated that HEls are not fully exploiting the possibilities that teaching and learning with digital technology potentially can provide (Ministry of Education and Research, 2018). For example, Norwegian students have reported that they experience the pedagogical use of digital technology in their education only to a small degree (Norgesuniversitetet, 2015). Several findings have indicated that enthusiastic teachers are still the driving forces for educational innovation, and that the 'digitalisation of higher education' is primarily an administrative effort. Some have argued, for example, that learning management systems (LMSs) have been adopted as administrative rather than educational systems (Norgesuniversitetet, 2015). 
These findings indicate that certain costs are involved in the translation of Norway's national ambitions on digital technology usage. Firstly, digital technology use is time-consuming. According to Lillejord and colleagues, researchers have reported that both teachers and students face challenges when learning occurs across formats. Blended and hybrid learning methods require increased time commitment from teachers, while students are expected to develop digital competence along with content specific skills (Lillejord et al., 2018). At the same time that these demands for new pedagogical practices for teaching and learning with technology have appeared, teachers and leaders is ought to address several conflicting and competing institutional demands. Secondly, the number of educational leaders who promote the integration of technology in quality work is limited. Digital technology usage is often characterised by a focus on the technology itself, where teachers can be assumed to have only technical needs, such as having an understanding of how new digital tools work and having a supportive environment in which to learn about them (Conole \& Fill, 2005). Aagard and colleagues found that a tool-based understanding in which traditional practices are digitalised still dominates, instead of focussing on how digitalisation can be used to transform and develop innovative pedagogical practices so that they will become more productive and relevant to society (Aagaard, Lund, Lanestedt, Ramberg, \& Swanberg 2018). Owens (2012) argues that in order for lecturers to develop digital technology usage in their teaching practices, they have both pedagogical and technical needs, as well as a need for support within the institution, such as support from their respective leaders. Systematic development also includes the strategies and processes of comprising digital technology usage in teaching and learning within curriculum development.

In a thematic analysis of the institutional hearings noted in the white paper on quality (Kunnskapsdepartementet, 2017), Aagard and colleagues investigated the extent of these hearings' connection of digitisation and education quality. They found that nearly all HEls and other organisations that responded to the hearing call (except NOKUT, the Norwegian Agency for Quality Assurance in Education) highlighted digitalisation as being vital for developing quality work in higher education. The authors also identified discrepancies between the ministerial call for educational leadership and the very few institutions that had connected digitalisation to locally led development work on pedagogical enhancement and academic leaders' quality work (Aagard et al., 2018).

Although this situation is not exclusive to Norway, the objective of this chapter is to further explore digital technology usage by examining how educational leaders and teachers interpret and translate Norway's national ambitions on technology usage in terms of quality work. 


\section{Translations and translational costs when using digital technology in quality work}

HEls are organisations with social and functional purposes (Giddens, 1991) that can be realised in a number of ways, for example by the means of digital technology. The latter can in this case be regarded as a form of 'institutional translation' of national Norwegian ambitions. Røvik $(2007,201)$ has argued that institutional translation (in our case, the processes on digital technology usage in higher education) requires educational leaders who possess knowledge, authority, and legitimacy to give the translation a better chance of success. A key form of reasoning in translational theory is that ideas such as digital technology use in higher education - are adopted, changed, and transformed by different actors (such as the programme leaders and teachers in our study) when integrated into new contexts (Czarniawska \& Joerges, 1996; Brunsson \& Olsen, 1990). This happens because they undergo different evaluations and reasoning (cf. Czarniawska \& Joerges, 1996), which are expressed in the actual translation. Ideas such as technology usage move, travel, transform, and materialise in ways that can become a stage for further action and other translations. This way the original ideas and the context in which they emerge are transformed (Czarniawska \& Sevòn, 2005).

Within HEls, technology usage as a phenomenon is not static and needs to be negotiated, distributed, and translated within the organisation, a process that often includes additional translational costs. One key notion comes from Weick (1976), who used educational organisations as a case when arguing that universities are examples of how 'loosely coupled' systems are both prevalent and important for organisational functioning. The formal structures, goals, and activities are only a part of the picture, according to Weick; the informal, chaotic parts can also be productive. A variety of strategies, involving language, rituals, events, the use of time and the way physical spaces is redesigned are some of the elements involved when external environments is "enacted" (ibid). The term 'loose coupling' conveys the image that coupled events are responsive but that each event has an individual identity; the coupling can vary over time and leaders needs to reaffirm and solidify those ties that do exist p. 276). In line with ideas within translation theory, leaders are responsible not only for being competent in evaluating ideas (before translating them) but also in 'reading and connecting' signals from the various parties involved. Røvik $(2007,2014)$ highlights leaders 'translator competence' as important, needed in order to carry out change and translation processes. Translator competence refers to the ability to translate practices and ideas (for instance) within or between organisational contexts and actors in a way that will give the process a better chance of success (Røvik, 2007). But change and translation in the educational programmes and research activities of HEls are not exclusively a question of leadership. On the contrary, HEls are often portrayed as the opposite - rooted in academic autonomy, 
high standards of academic excellence, and an associated academic professional structure (Schofer \& Meyer, 2005).

There is no clear evidence that digital technology usage is especially prioritised on most academic leaders' agendas. According to Bryman's (2007) literature review on academic leaders, for example, such leaders' responsibilities are very broad and contextually bound, with a tendency to display a range of competing competencies and priorities that sometimes clash. Tømte et al.'s (2016) findings from a survey revealed that about half the deans at all public Norwegian HEls reported having no or limited knowledge about how their own faculty addressed issues related to digital technology usage for teaching and learning purposes.

Scholars of neo-institutional theory have highlighted the importance of shared 'logics' or 'realisations' when defining institutions (Di Maggio \& Powell, 1991) and have explored issues of institutional change (Alvesson \& Spicer, 2018) that are relevant when analysing digital technology usage as a driver for change in educational quality work. The logics of universities are said to be rooted in the search for universal knowledge, academic autonomy, standards of excellence, and an associated academic professional structure (Shields \& Watermeyer, 2018). Implementation of policy at universities are often seen as challenging, as universities can be described as loosely coupled organisation with a strong hierarchy of teachers' operation in the ethos of academic freedom (Schwenk 1999).

Recent work has also focussed on the multiple, competing, and even contradictory logics that often occur simultaneously (Greenwood et al., 2011). Shields and Watermeyer (2018) suggest three main competing institutional logics within universities in their conceptual and empirical framework: - the autonomous, the utilitarian, and the managerial. They argue that these multiple logics produce competing models of the university as an institution that have both practical and theoretical implications within the institution.

Table 1: A conceptual and empirical framework for measuring universities' competing logics (Shields \& Watermeyer, 2018, p. 9)

\begin{tabular}{|l|l|l|}
\hline Autonomous universities... & Utilitarian universities... & Managerial universities... \\
\hline -provide forums for debate & -provide students with employable & \\
-encourage critical thinking & skills & -are hierarchical \\
-provide social critiques & -develop knowledge for economic & -are bureaucratic \\
-develop knowledge that & growth \\
improves society & -encourage entrepreneurialism & -are similar to businesses \\
\end{tabular}

Note: The framework has three dimensions, with four indicators for each dimension. 
In this chapter, we use the translations perspective to investigate the bridge between the national ambitions and the processes involved in technology usage in selected HEls. Because our analytical approach is based on translation theory, a key element of our reasoning is that different people adopt, change, and transform ideas when they integrate them into contextual quality work. We use translational theory analytically to distinguish the broader ambitions regarding technology use within the various policy developments and processes that take place in the local context. The diverse and complex ways in which technology usage is made sense of, adopted, or ignored are important parts of the ongoing translations of how educational leaders and teachers use digital technology in their institutional quality work, which may be influenced by competing logics.

\section{Methodological approach}

The data used in this chapter are derived from the QNHE research project. This allowed us to address our research question from three distinct levels within higher education (Clark, 1983): the suprastructure (macro or system) level, the middle-structure (institutional or meso) level, and the understructure or micro (teaching and learning context) level. At the institutional level we have undertaken a document analysis of institutional strategic plans and annual reports related to the institutions analysed in the QNHE project. In addition, we have used data from a survey of study programme leaders (SPL), as well as interviews with educational leaders. The "under-structure" perspective comprises interviews and observational data from a case study of a particular course at one of the case HEls of the QNHE project (HE 3). Table 2 presents our data sources according to these three perspectives.

Table 2: Overview of data sources

\begin{tabular}{|l|l|l|l|}
\hline Level & Type of data & Specification of data and informants & Institutions \\
\hline $\begin{array}{l}\text { Super } \\
\text { structure }\end{array}$ & Documents & Governmental white paper & $\begin{array}{l}\text { Ministry of Education and } \\
\text { Research }\end{array}$ \\
\hline $\begin{array}{l}\text { Middle } \\
\text { structure }\end{array}$ & Documents & $\begin{array}{l}\text {-Institutional strategies } \\
\text {-Annual reports }\end{array}$ & All selected institutions \\
\hline $\begin{array}{l}\text { Middle } \\
\text { structure }\end{array}$ & Survey & Study-programme leaders (SPLs) & $\begin{array}{l}\text { All HEls in Norway (N = } \\
551)\end{array}$ \\
\hline $\begin{array}{l}\text { Middle } \\
\text { structure }\end{array}$ & Interviews & Educational leaders & Six selected cases \\
\hline $\begin{array}{l}\text { Middle } \\
\text { structure }\end{array}$ & Documents & Study-programme documents & Six selected cases \\
\hline $\begin{array}{l}\text { Under- } \\
\text { structure }\end{array}$ & $\begin{array}{l}\text {-Observation } \\
\text {-Interviews } \\
\text {-Documents }\end{array}$ & $\begin{array}{l}\text { Teachers and students at a specific } \\
\text { course within an MBA programme }\end{array}$ & HE 3 \\
\hline
\end{tabular}


Please also note that these three levels serve to illustrate the dimensions of quality work, although they do not illustrate causality dimensions between the levels as such.

\section{Institutional strategies}

Two types of data sources cover our analysis of institutional strategies: annual reports from 2010-14 and overall strategy and planning documents from 2014-18, all drawn from three selected HEls: HE 1, HE 2 and HE 3. In all documents we undertook systematic searches for the terms 'digitalisation' and 'technology' and coded the context in which these terms were mentioned. We organised the findings by each HEI before making subcategories of the findings from each HEI in order to frame the distinct contexts, which enabled us to identify similarities and differences across the institutions. Within the institutional strategy documents and annual reports, we searched for elements of digital technology and the extent to which they were typically posed as elements for improving teaching and learning within the study programmes. In our analysis of these types of documents, our aim was to explore in which contexts digital technology usage was promoted.

\section{Leadership practices}

Leadership practices were derived from two empirical sources: a survey among SPLs and interviews with educational leaders. The survey, conducted in Norway in spring 2016, addressed several topics on the role and responsibilities of the educational leaders, including three questions covering digital technology dimensions.

The purpose of the interviews with the educational leaders in the QNHE project was to understand their strategic thinking and priorities as leaders of quality work within their institutions. In this chapter, we selected a subsample of interviews coupled to our selection of study programmes from the three selected institutions (HE 1, HE 2, and HE 3). This means that educational leaders followed the 'quality chain' from the top leaders to the SPLS.

\section{Teacher practices}

The data on teachers' use of digital technology were derived from one of eight in-depth case studies on teaching and learning practices at the course level within the QNHE project: online teaching and 
learning in an experience-based MBA programme at $\mathrm{HE} 3^{2}$. All eight case studies addressed the opportunities and challenges teachers and students face in their everyday educational activities, and all involved issues related to how technology affected various types of student-active learning in different ways. The actual MBA case study provided information about how an online course design proceeded both challenges and opportunities that teachers and students encountered within this selected context. The educational practice analysis thus focusses on teaching and learning activities (based on selected modules/course segments), supported by interview data, with both educational leaders and teachers providing insights into the 'micro-politics' of digital technology use in teaching and learning practices.

\section{Limitations and analytical scope}

Two types of educational leaders are included in our dataset: study program leaders (SPLS) and other educational leaders responsible for developing educational practices. This distinction is confusing, as there are several ways to define these formal positions as well as the practices that these leaders are responsible for. Moreover, the SPLs may combine their roles as educational leaders and teachers, in that in most cases SPLs also teach within the programme for which they are responsible. Finally, especially among the larger HEls, the SPLs have virtually no strategic responsibility. When reporting on these two levels, we will thus explicitly mention their roles as either educational leaders or SPL.

The different empirical sources were triangulated using the nationwide survey of SPLs and systemlevel analyses of study programmes. In addition, the selected in-depth case study was used for examining conditions for quality work across and within institutions. We synthesised the many different datasets into a 'thick' description to inform the reader of certain trends and perspectives on how digitalisation in HEls is translated and managed within quality work in education.

\section{Findings}

The empirical findings are organised into three main sections: (1) strategic plans and other institutional documents at the central institutional level, (2) educational leaders' practices (both statistically and

\footnotetext{
${ }^{2}$ To get a more detailed overview of the data related to all eight cases, see Nerland \& Prøitz (2018).
} 
through document analyses and interviews), and (3) selected case study, which involves the in-depth teaching and learning processes of institutional practices in quality work.

\section{Strategies and institutional quality work}

The strategies reflect high institutional ambitions towards quality work related to digital technology usage in terms of innovation, active and varied teaching and learning methods, and new ways of collaborating and communicating across campuses. These statements are consonant with the governmental white paper on quality in education, which also stresses a pedagogical shift towards active and student-centred teaching and learning, in where technology might serve as key drivers. The strategies have in common that they are bold in their ambitions, express aims to 'become a leading $\mathrm{HEI}^{\prime}$, and brand digital technology as a central tool for institutions to achieve future challenges and various university goals. The institutional strategies state that technology ought to be used to enhance teaching and learning practices, attract students, and promote educational quality in education as essential. Their more general ambitions to become prominent or "the best" on digitalisation is highlighted, but some of the annual reports also describe quality work related to technology in more detail.

Institutions also stress the need for support and effective infrastructure as well as the importance of sharing ideas. When we looked more closely at the selected HEIS (HE 2, HE 3, and HE 1), we found specific approaches that were partly influenced by the institutional profile of each of the three and partly related to national ambitions towards digitalisation among HEls. HE 3's focus on digital technology usage in teaching and learning is clearly expressed in its institutional strategies on educational quality and didactics. The university's strategic thinking is closely associated with its multicampus profile. During the period 2011-14, there was a distinct strategic focus area at HE 3: flexible education (in Norwegian, 'fleksibel utdanning'), the aim of which is to explore the possibilities that come with distance and flexible education using the support of technology. The university continued this approach in a new strategic focus area: the programme for educational quality (in Norwegian, 'program for utdanningskvalitet') starting in 2014 (HE 3, annual report 2014, p. 10). In 2014, the university further explored these intentions towards educational flexibility for continuing-education purposes and with an eye on the possibilities that come with large-scale online education programmes, such as massive open online courses (MOOCs). HE 3 emphasises that quality work is closely connected to the teachers' digital and pedagogical competences. In recent years, the university has laboured to increase the status of its educational and pedagogical competence, and, together with HEI 4, it has pioneered an institutional approach to pedagogical merits. 
We found that the institutions prioritised the introduction of digital exams and alternative digitalassessment forms, while they also promoted student learning through digital technology usage. HE 2 is one example; as the university stated,

[the] increased use of digital solutions in education is an important focus, and the "digitalisation" programme was expanded in 2014. Digitalisation efforts will help to promote learning and students' learning outcomes. The focus includes a new web-based learningsupport system, the stimulation of new digital student-active learning methods, and tools for recording and streaming lectures. We highly prioritise digital exams and alternative digitalassessment forms. (HE 2, 2014, p. 11)

HE 2 then highlighted that it has continued to develop future-oriented teaching and student-active learning and has strengthened the pedagogical dimension within digitalisation processes in terms of teaching and assessment. Another observation is that distinct strategic documents address technology usage, such as the digitalisation strategy at HE 3. We also observed other efforts, such as the establishment of several strategic arenas that promote the use of digital technology and quality work in order to attain overall institutional strategic ambitions. Some of the institutions had established distinct programmes to promote and support innovative ways of developing quality work in teaching and learning, such as HE 1:

The 'Outstanding Professional Qualification' programme ... cooperates closely with HE 1's education programmes and students to support specific research and development ... initiatives, develop new and innovative ways of teaching, and to document and organise existing initiatives and experiences. The programme creates learning arenas digitally and, through meetings and workshops, develops quality indicators and stimulates quality development. (HE 1, annual report, 2014)

Another observation is that specific 'strategic focus areas' can be inspiring for the institution as a whole. HE 3, for example, takes a systematic approach to supporting initiatives from departments with developmental projects on teaching and learning or leadership development, as noted in its 2014 annual report: 
The Teaching Quality Programme is one of HE 3's strategic focus areas. The project is a continuation of the former project 'Flexible Education' (2011-2014).... Members of all departments at HE 3 can apply for support. The funds are divided into three categories: 'seed', 'development funds', and 'lighthouse funds'. [These funds] can only be applied within one area and for a year at a time. A total of NOK 2.8 million was distributed among eleven seed applications, and nine in the category of development funds. Lighthouse funds, totalling NOK 1.5 million, are distributed by the Strategic Education Committee starting 24 February, 2015. In addition, the university board has set aside NOK 1.7 million for the 'digital exam' project. (HE 3, annual report, 2014, p. 10).

In this setting departments can apply for funding when the development of quality work on teaching and learning is the key. The establishment of a central strategic educational council was driven by the leadership and included all vice-deans, representatives from central leadership, administrators, students, and the resource centre for teaching, learning, and technology. Even though the amount of available funding is typically limited, numerous educational staff apply for the funds; the initiative is meant to translate the university policy and to promote and stimulate bottom up-initiatives and developments from the working floor of the institution.

Although we found strategic focus areas related to teaching and digital technology usage at all three universities, few of these strategic ambitions had been operationalised and translated into actions and strategies at the faculty, department, or study-programme level. When we looked into possible translations of the institutional strategies (departmental and study-programme documents), the broader picture we found was that they could be characterised as decoupled (Weick, 1976) and "tooloriented" (Norgesuniversitetet, 2015). All three institutions highlighted that technological infrastructure was the basis for further work on quality at all levels within the institution. HE 2, for example, suggested that digitalisation would support administrative staff, with the aim of having them work more efficiently with educational staff and students. HE 3 highlighted the geographical multicampus perspective, since such an approach is related to technological infrastructure. Technological infrastructure thus serves as a foundation for quality work within the institutions to include administrative and digital technology usage in teaching and learning.

\section{Leaders practices and institutional quality work}

In our interviews with educational leaders, and in the survey distributed to the SPLs, we found a mismatch with the institutions' own strategic ambitions, as this was formulated in the institutional 
documents. We did not find the clear and strong institutional intention of putting 'technology work' high on the institutional agenda to have been translated by the educational leaders and SPLs within the selected institutions. We asked the SPLs three different questions on digital technology usage in teaching:

(1) How central is digital technology usage in the development of teaching and learning activities?

(2) What is the extent of technology usage in your study programme?

(3) What forms of technology support have been provided? ${ }^{3}$

When programme leaders describe their "quality" work, the findings illustrated in diverse ways that technology usage was not a very highly prioritised area where organised development was a part of the quality work within the study programme. However when asked in the survey, as illustrated below by the different institutional categories, they still report that it is.

Table 3: To what extent is digital technology usage central in the development of teaching and learning activities at your institute/department? By type of institution ${ }^{4}$, in percentages (Aamodt et al., 2016)

\begin{tabular}{|l|c|c|c|c|c|}
\hline & $\begin{array}{c}\text { Universities, } \\
\text { before 2005 }\end{array}$ & $\begin{array}{c}\text { Specialised } \\
\text { colleges }\end{array}$ & $\begin{array}{c}\text { Universities } \\
\text { after 2005 }\end{array}$ & $\begin{array}{c}\text { University } \\
\text { Colleges }\end{array}$ & Total \\
\hline No response & $12 \%$ & $10 \%$ & $19 \%$ & $13 \%$ & $14 \%$ \\
\hline $\begin{array}{l}\text { To a small/no } \\
\text { degree }\end{array}$ & $10 \%$ & $5 \%$ & $6 \%$ & $8 \%$ & $9 \%$ \\
\hline $\begin{array}{l}\text { To some } \\
\text { degree }\end{array}$ & $57 \%$ & $52 \%$ & $51 \%$ & $45 \%$ & $50 \%$ \\
\hline $\begin{array}{l}\text { To a strong } \\
\text { degree }\end{array}$ & $20 \%$ & $33 \%$ & $24 \%$ & $34 \%$ & $27 \%$ \\
\hline $\mathrm{N}=100 \%$ & 187 & 21 & 93 & 250 & 551 \\
\hline
\end{tabular}

The discrepancy between what they say is important and what they actually describe that they do, can be understood as an expression for a lack of implementation practices. As found in previous studies (Fossland and Gabrielsen 2017), the idea of technology use is widespread within the organisation, but lacks implementation and operationalisation of "quality work". We found a similar picture when we

\footnotetext{
${ }^{3}$ These findings on technology usage from the project were first published in a working paper (Aamodt et al., 2016).

${ }^{4}$ Since 2003, the public higher education sector in Norway has changed from four universities, seven specialized universities and 25 university colleges (somewhat parallel to the Danish university colleges) into eight universities, five specialized universities, and eight university colleges in 2017.
} 
asked the same SPLs about the important of digital technology for improving teaching and learning within their departments. Although we found a few differences among different faculties, the broader picture was that digital technology usage was not highly prioritised at the study-programme level; departments within the humanities, technology, and medicine fields reported somewhat higher priorities than the social sciences and technical/mathematics departments (Aamodt et al., 2016).

When we looked into the local strategic documents, we found only a few elements that were directly coupled to the overall ambitions related to technology usage to enhance teaching and learning. Within the institutional programme plans, the technology dimension seemed to have been largely left out, with some exceptions where digital technology was mentioned in more general terms. We found very few documents where the institutional strategies had been translated into concrete action plans. The interviewees also showed a clear tendency that technology was not a central part of what educational leaders defined as their quality work. When asked how they viewed their role as educational leaders, and what their main tasks were, very few mentioned that technology was among their highest priorities. We may interpret that their answers, both in the programme-leader survey and the interviews, indicated their perspectives on their roles and responsibilities as educational leaders. The main picture was that the education leaders' strategies largely were disconnected from the more overarching strategies on technology in their daily quality work. In line with Weick's study (1976), their quality work related to technology was loosely coupled to what the leaders considered their most important tasks. The educational leaders had many other issues on their agendas, which may explain why they did not prioritise technology usage as something they would be held specifically accountable for, as one leader from HE 2 noted:

... within research, nearly everything is about development; within education, it quickly becomes a question of daily operations and routines. Routines, quality assurance, systems, all these things that must be dealt with, and all the things we're asked to report on - they don't end up anywhere, and that feels a bit meaningless (centre manager, HE 2).

In line with Bryman (2007), this quote illustrates that leaders' responsibilities and quality work was broad and included many elements they were required to do that did not end up in educational development or practices and processes involved in quality enhancement that 'mattered'. Even though we found exceptions at all three universities, one observation was especially interesting: one of the universities was experiencing extended multi-campus challenges, which was reflected in more awareness of digital technology usage in relation to those specific challenges. As one leader said, 
... since we have a multi-campus structure, we make full use of it... In terms of competence, we're not only concerned with closing the formal gap; students should have an added value, [which] is precisely that they learn to study with the help of modern technology.... (Head of department, HE 3)

In this multi-campus institution, the leadership was generally perceived as being very engaged in issues of educational quality, which was one of the topics the leaders promoted in the leadership elections. Although exceptions existed within all three institutions on strategies and incentives meant to promote technology usage, we found few notions about structures and strategies at the faculty level that were directed towards enhancing the teachers' and study programmes' quality work related to technology use. While further research is necessary - since we asked the leaders more general questions about their quality work and their role as leaders - we may conclude that the overall impression was that technology usage was not prioritised to a large extent in their daily quality work, as few reported that their quality work was directly related to technology usage.

These findings indicate that institutional quality work at the faculty level is loosely coupled to the national and institutional ambitions related to digital technology usage (Weick, 1976). A few translational costs may arise when translating these ambitions at the local level. While the data in our project do not provide any details that could clearly explain the whole picture, we confirm that some of the challenges revealed from previous research still exist (Lillejord et al., 2018). These challenges may involve translational costs such as multiple, competing, and even contradictory logics that occur simultaneously (Greenwood et al., 2011) like autonomy or bureaucratic requirements (Shields and Watermeyer, 2018), when "translating" the national and institutional ambitions on digital technology usage into pedagogical departmental practices, including practices on the study program- and courselevel.

Other explanations may be that the SPLs lack translator competences (Røvik, 2014), or that, to many people, multiple, competing, and even contradictory logics are of relevance simultaneously within the study programme is found to be more accepted by educational staff than technology usage (Greenwood et al., 2011; Shields \& Watermeyer, 2018). Our findings may also indicate that technology usage is not a high priority in actual quality work. Translational costs such as time-consuming elements related to technology use, challenges related to the lack of providing adequate technical or pedagogical support as well as lack of effective incitements to invest in developmental efforts, may be arguments that partly explain why technology usage is challenging at the departmental and study program level. In line with what others studies on technology usage has found (Owen, 2012, 
Norgesuniversitetet, 2015)), our findings from the survey may indicate that technology usage was not very high on the SPLs' agendas; they reported, not surprisingly, that LMS usage was particularly prominent. Even though they were positioned to "translate" the institutional strategies on technology use, several translational "costs", lack of time and competing institutional logics made other obligations more prioritised.

\section{Teachers practices and quality work}

One overall observation across the eight in-depth case studies on the course level demonstrated that a range of activities and pedagogical approaches, including various use of digital technology were combined in courses and led to complex environments for teaching and learning. In line with previous studies (Norgesuniversitetet, 2015), we found a tendency that learning management platforms played a central role in digital technology usage. Moreover, we observed little attention towards professional development of teachers' digital competences. The overall conclusion was that higher education practices, and especially their more student-activating modes, counted a range of dilemmas and challenges, including digital technology use (Nerland \& Prøitz, 2018).

If we look to the case study related to one course with a blended learning design, one key observation was that the facilitation of online teaching and learning processes required other types of competences, pedagogical approaches, and general awareness than those associated with solely campus-based teaching and learning contexts (Fossland \& Tømte, 2019). Students only attended one voluntary start-up gathering on campus; they accessed their course via the learning-management platform to gain access to peers, teachers, course content, and administrative information. One interesting observation was that, with a few exceptions, teachers with teaching responsibilities within this program did not follow the students closely and did not invest time to enhance their technology usage related to their teaching and students learning process. The program leader expressed it like this;

One of the biggest challenges is that most of the academic staff do not have the necessary digital competence. They are not following up on the students in the VLS (virtual learning systems)... as these programs requires another form of presence from the teachers in order to be able to communicate with students that is outside campus (program leader, HE 3).

The importance of professionalising the administrative and academic staff in order to meet the requirements related to digital technology usage were apparent. Even though some of the teachers 
more closely followed their students learning processes and were interested to develop their technology usage, it is obvious in the teachers' interviews that improving their digital competences was not highly prioritised and that it required leadership involvement as well as a will to translate and involve the academic staff. Our findings indicate that both educational leaders and academic staff did not hold, or sufficiently prioritised to develop their digital competence, in line with the overall institutional ambitions. The teachers were rarely offered or invited to develop their digital competences, only a few incentives were found to be promoted in their daily quality work and teaching practices.

The case also showed that the educational leaders were not fully aware of how to support the teachers involved, for example, in ensuring that they would have access to adequate resources and facilitate the usage of technological infrastructure, or in aligning administrative systems to their type of students - adult learners in this case (ibid.). There are several possible explanations for this situation. Our interviews with the leaders indicated that they had difficulty getting teachers to prioritise their digital responsibilities, other than to learn what was strictly necessarily to fulfil their agreement to film some of their teaching. We found several competing logics occurring simultaneously (Greenwood et al., 2011, Shields and Watermeyer, 2018) like autonomy, that teachers prioritised their research or that they preferred following a strict line between the teachers' responsibilities and administrative mandates. One leader said that it was 'difficult to interfere with how employees teach'. Another challenge the leaders mentioned was that the teachers did not want to spend their time on the timeconsuming elements related to digital technology usage and the challenges they often meet when learning happens across formats (Lillejord et al., 2018). Our findings have revealed that teachers with ambitions related to the use of digital technology in quality work, still appear as 'enthusiasts', in line with the findings of previous researchers (Aagard et al. 2018, Norgesuniversitetet 2015).

\section{Discussion}

In this chapter, we have examined how educational leaders and teachers "translate" Norway's national ambitions on digital technology usage within institutional quality work. We have studied how key institutional documents and study programmes have addressed issues on quality work related to technology use, and how the educational leaders' and teachers' practices in their quality work relate to these documents. In line with Weick (1976) our findings demonstrate that the problem lies in the mismatch between institutional ambitions on the use of digital technology and the translation of these ambitions in the quality work at the study programme- and course level. One key observation is that 
the practices and processes involved in technology enhancement are influenced by several translational costs that create a mismatch between national strategies and the educational leaders' and teachers' practices. In the following paragraphs we will elaborate further on these findings.

\section{Translational costs related to external drivers}

The ministerial white paper 'Culture for Quality in Higher Education' emphasised the need for a cultural shift to promote quality work within higher education in Norway. We have found that to a large extent, the quality work related to teaching and learning practices and processes involving digital technology usage for quality enhancement still rely on external drivers. Some of these drivers include (1) teaching and learning centres or external systems determined by HEls' quality-assurance or external evaluations, (2) the use of LMSs or national initiatives such as e-campuses, and (3) the use of systems placed outside the academic context of teaching and learning processes at the departmental level, instead of facilitating and building up resources near the teaching and learning contexts and in relation to the involved leaders and teachers.

Stensaker et al. (2007) state that the actual institutions' response to external drivers was to establish overall strategies and to stress the provision of adequate technological infrastructure and overall visions. Ten years later, as demonstrated, most HEls have such strategies at place. Nonetheless, another issue flagged by Stensaker et al, namely to communicate the overall purposes of technology, and how that technology should be linked with staff and pedagogy, remains a significant challenge that must be dealt with.

\section{Translational costs involved in educational leaders' connection to institutional strategies}

Our findings have revealed that the institutional strategies are highly ambitious on digital technology usage to meet future challenges. In contrast to these strategies, the programme-leader survey and the interviews with the educational leaders clearly showed weak intra-institutional strategic coupling between the institutional ambitions and the actual quality work (Weick, 1979). Although the selected HEls in the QNHE project had launched overall strategies and had committed to digital technology usage, we found:

(1) that the focus was on overall processes and was not translated into concrete quality work related to the practices and processes involved in quality enhancement; 
(2) little evidence of overall purposes and strategies on ways to couple technology to staff, pedagogy, and educational development within the institutional plans;

(3) that the focus was more on digital technology per se than on enhancing educational practices and the pedagogical use of digital technology.

We cannot clearly state that these findings can be explained by a lack of leaders' translator competence (Røvik, 2014) or simultaneously ongoing responsibilities with competing institutional logics. Even if the ability, time, or will (or a combination of these elements) might be plausible various explanations, we did find that the translation of practices related to technology usage was not generally a high priority. Local strategies and politics on prioritising the development and quality work of teaching and learning with digital technology have the clear potential to become more 'on task'. Our findings indicate that one part of the question is related to the fact that leaders need to possess knowledge (on technology and pedagogy), authority, and legitimacy to lend the translation a better chance of success (Røvik, 2014).

\section{Translational costs in the teachers' contextual reality}

Related to meeting the institutional strategies and national ambitions on digital technology usage in local quality work, we have identified several challenges that can be characterised as translational costs. In line with previous studies (Lillejord, 2018; Aagard et al., 2018), we found several barriers to quality work related to digital technology usage, including the following.

(1) Structural elements - such as the teachers' working hours, their perceptions of their responsibilities, the opening hours of the help desk, and how lecture halls were equipped revealed several challenges related to the teachers' use of technology in their quality work.

(2) Teachers who used technology clearly had to take extra time because of the translations they had to do to make things work.

(3) Teachers' quality work, practices, and processes that involved a special focus on technology seemed to be left to individual enthusiasts to solve on their own, since very few collective initiatives were available for support.

(4) The pedagogical use of technology as quality work was not interwoven into the collegial collaboration between teachers; their teaching to a large extent was understood to be due to their individual and private efforts. 
The main result of these translational costs was that the teachers did not collaborate on their teaching methods or plan how technology would be a holistic part of their daily quality work.

The educational leaders' and teachers' quality work largely appeared to be decoupled (Weick, 1976) from the institutional strategies on teaching and learning with digital technology. The leaders' work was focussed on activities that were reported for managerial purposes and other competing quality ideas; the teachers seemed to be concerned that they would lose time that they otherwise could have used on research. This view does not mean that they saw issues related to technology as unimportant, as demonstrated in the survey, but other practises and competing logics appeared to be more of a priority in their daily quality work. Leaders' responsibilities were not found to be reinforcing and solidifying the purposed coupled elements concerning technology usage at the department level. We also found clear indications that both teachers and leaders themselves needed to possess and develop digital skills in order to exploit opportunities related to pedagogical use of technology within their own departments. These findings indicate that technology usage needs to be negotiated through what Weick (1976) has outlined as a variety of strategies, involving language, rituals, events, the use of time as well as the redesign of physical spaces, when external environments (like the request for technology use) is "enacted" (ibid). Weick (1976) argue that leaders' needs to actively strengthen organisational ties or couplings in loosely coupled institutions, like the connection between institutional strategies and the ongoing quality work. He also argued that informal, chaotic parts can be productive, which might explain the many positive initiatives we found arising from teachers, either individually or in groups.

These findings indicate that ongoing competing logics (Shields \& Watermeyer, 2018) are a part of the picture when translating institutional ambitions on digital technology usage as a driver for change in educational quality work - a situation that requires further investigation. Even though we have found clear tendencies of what Greenwood et al. (2011) characterise as multiple, competing, and even contradictory logics going on simultaneously related to different positions involved in the local quality work at the institutional level, further research must be conducted to investigate these mechanisms in more depth. Some of the tendencies that must be further elaborated upon include (1) the responsibilities related to the translation of institutional ambitions vis-à-vis digital technology usage and (2) the responsible leaders' potentially limited understanding of what the translation of institutional ambitions means in terms of securing digital competence among the staff and students involved in order to support and develop student-active learning.

We believe that the awareness of digitisation and the limited engagement of highlighting the development of teaching and learning through the use of digital technology could also be a result of 
several reforms that have challenged the institutions' hierarchical governance, such as the recent merging processes within Norwegian HEls. These reforms have led to more hybridised and loosely coupled organisational and governance forms. Our findings can also be seen in relation to the fact that all Norwegian HEls have implemented internal systems of quality assurance, often manifested through student evaluations of teaching (Michelsen \& Aamodt, 2007). We may interpret this finding as a gap between the leaders' awareness and responsibility for digitalisation and their involvement in what we have earlier described as national ambitions related to digital technology usage.

This situation has emerged while an overall change in perspective at the national level has occurred from more teacher-led education towards more student-active learning. We may expect this renewed attention to how technology may enhance various forms of teaching and learning activities to be found in overall strategies within HEls and institutional documents, and to some extent in distinct study programmes and courses. This governmental interest has resulted in the establishment of national performance-indicator systems, external quality-assurance systems, and an increase in public-funding arrangements linking performance to resource allocation (Damsa et al., 2015). These systems do not focus directly on the educational quality work, but they may address how technology has a potential to be included to enhance quality work. The key take away would be that technology serve as one out of several 'duties' of the work plan of academic staff; how they translate those duties must be understood in the larger complex context of which competing institutional logics influence leaders' and teachers' quality work.

\section{Conclusion: Challenges, possible solutions, and future research}

The national ambition that teaching and learning with digital technology can improve educational quality and student learning has been solidly rooted in European (and Norwegian) higher education policies for the last two decades. Our study has indicated that HEls still face profound challenges related to translational costs regarding national and institutional ambitions to enhance teaching and learning via technology. Even though several initiatives, both internationally and from the Norwegian government, have been undertaken to implement technology in the practices and processes involved in quality enhancement, we have found few indications of a collective orientation towards digital technology usage. There is a need for further research to investigate the mechanisms connected to these findings in more details. This finding contrasts the national call for a 'quality culture' with the ultimate goal of enhancing teaching and learning with digital technology in higher education. On contrary, our study demonstrates that collective initiatives are moving slowly. 
This chapter underlines the importance of understanding translational costs related to local challenges, competing institutional logics, and leaders' and teachers' own responsibilities and actions regarding the complexities of quality work. To fully understand quality work related to technology, we suggest new contextual studies to follow more closely quality-enhancement orientations related to technology usage. Even though technology usage in teaching and learning processes is high on Norway's national agenda, we have found several indications of a mismatch between the national ambitions and the institutional contextual quality work. There is thus a match and a mis-match. The institutional strategies are in line with the national ambitions, while a mismatch is observed when it comes to the actual practices at the departmental, program and course level. In other words, while (1) strategies for the implementation of teaching and learning with digital technology for educational purposes are moving in the right direction, (2) the overall strategies have stressed the provision of adequate technological infrastructure and overall visions, and (3) the established infrastructure is generally considered important for successful implementation, we have found that translating and likewise communicating the overall purposes of technology and how such technology should be linked with staff and pedagogy remains unsolved.

Future research needs to more closely delve into the institutional practices and translational costs involved in order to fully understand how national and institutional strategies on digitalisation are related to, and translated within, the different levels of the organisation. Researchers should also examine the consequences of different strategies on digitalisation in relation to different teaching and learning strategies within HEls. Moreover, we suggest that researchers should scrutinise digital competence among teachers and leaders, since they make decisions about including digital technology in their daily quality work; an additional aim could be to challenge so called "tool-based" orientations when it come to the use of technology for teaching and learning. The fact that enthusiastic teachers are still an important driving force for change must be addressed and critically analysed. Newer research, as suggested here, would be significant contributions to shed light on necessary requirements to establish the quality culture the recent white paper on quality in higher education has called for.

\section{References}

Alvesson, M. \& Spicer, A. (2018) Neo-Institutional Theory and Organization Studies: A Mid-Life Crisis? Organization Studies, 40(2), 199-218. https://doi.org/10.1177/0170840618772610 
Bryman, A. (2007). Effective leadership in higher education: a literature review, Studies in Higher Education, 32(6), 693-710. DOI: 10.1080/03075070701685114

Brunsson, N. \& Olsen, J.P. (1990). Makten Att Reformera. Stockholm: Carlssons.

Clark, B.R. (1983). The Higher Education System: Academic Organization in Cross-national Perspective. University of California Press.

Conole, G. \& Fill, K. (2005). A learning design toolkit to create pedagogically effective learning activities. Journal of Interactive Media in Education, 1(9). DOI: http://doi.org/10.5334/2005-8

Czarniawska, B. \& Sevòn, G. (2005). Translation is a vehicle, imitation its motor, and fashion sits at the wheel, B. Czarniawska, G. Sevón (Eds.), Global ideas. How ideas, objects and practices travel in the global economy (pp. 7-12). Malmö: Liber \& CBS Press.

Czarniawska, B. \& Joerges, B. (1996). Travels of ideas. In B. Czarniawska, G. Sevón (Eds.), Translating organizational change (pp. 13-48). Berlin: de Gruyter.

Damşa, C., de Lange, T., Elken, M., Esterhazy, R., Fossland, T., Frolich, N., Hovdhaugen, E., Maassen, P., Nerland, M., B., Nordkvelle, Y. T., Stensaker, B., Tømte, C., Vabø, A., Wiers-Jenssen, J., Aamodt, P., O. (2015). Quality in Norwegian Higher Education: A review of research on aspects affecting student learning. Report 2015:24. Oslo: NIFU

DiMaggio P. J. \& Powell W. W. (1983). The iron cage revisited: Institutional isomorphism and collective rationality in organizational fields. American Sociological Review, 48, 147-160.

Elken, M. \& Stensaker, B. (2018). Introduction. in this volume

Fossland, T. (2015). Digitale læringsformer i høyere utdanning. Oslo: Universitetsforlaget Fossland, T. \& Tømte, C., E. (2018). Online teaching and learning in an experience-based MBA programme. In Nerland, M. \& Prøitz, T. (Eds.). Pathways to quality in higher education: Case studies of educational practices in eight courses. (pp 136-151). NIFU Report 3/2018. Oslo: NIFU.

Fossland, T. \& Tømte, C. (2019). Deltaker eller tilskuer? En casestudie om vilkår for deltakelse og samarbeidslæring i et nettbasert masterprogram i økonomi og ledelse (MBA) UNIPED, 42(1), 41-59.

Frieedland, R. \& Alford R., R. (1991). Bringing society back in: Symbols, practices and institutional contradictions in Powell, W. W, Dimaggio, P. J. (eds.) The New Institutionalism in Organizational Analysis (1991), 232-263

Giddens, A. (1987). Social Theory and Modern Sociology. Stanford, Calif.: Stanford University Press. 
Greenwood, R. M., Raynard, M., Kodeih, F., Micelotta, E.R. \& Lounsbury, M. (2011). Institutional Complexity and Organizational Responses. Academy of Management Annals, 5(1), 317-71.

https://doi.org/10.5465/19416520.2011.590299

Hempsall, K.(2014) Developing leadership in higher education: Perspectives from the USA, the UK and Australia, Journal of Higher Education Policy and Management, 36(4), 383-394. DOI: $10.1080 / 1360080 X .2014 .916468$

Kunnskapsdepartementet (2017). Meld. St. 16: Kultur for kvalitet i høyere utdanning. Oslo: Kunnskapsdepartementet. Retreived from:

https://www.regjeringen.no/contentassets/aee30e4b7d3241d5bd89db69fe38f7ba/no/pdfs/stm2 $\underline{01620170016000 d d d p d f s . p d f}$.

Lillejord S., Børte K., Nesje K. \& Ruud E. (2018). Learning and teaching with technology inhigher education - a systematic review. Oslo: Knowledge Centre for Education www.kunnskapssenter.no Norgesuniversitetet, 2015. Digital tilstand. Norgesuniversitetets skriftserie nr. 1/2015, Troms $\varnothing$. Retrieved from. https://norgesuniversitetet.no/skriftserie/1-2015-digital-tilstand-2014 Michelsen, S. \& Aamodt, P.O. (2007). Evaluering av kvalitetsreformen - sluttrapport. Retrieved from https://brage.bibsys.no/xmlui/bitstream/handle/11250/279245/Evaluering-av$\underline{\text { Kvalitetsreformen-Sluttrapport.pdf? sequence }=1}$

Nerland, M. \& Prøitz, T., S. (eds.) (2018). Pathways to quality in higher education. Case studies of educational practices in eight courses. NIFU report 2018:3

Owens, T. (2012). Hitting the nail on the head: the importance of specific staff development for effective blended learning, Innovations in Education and Teaching International, 49(4), 389-400. DOI: $\underline{10.1080 / 14703297.2012 .728877}$

Røvik, K.A. (2014). Translasjon - en alternativ doktrine for implementering. K.A. Røvik, T.V. Eilertsen og E.M. Furu (red). Reformideer I norsk skole - spredning, oversettelse og implentering. Oslo: Cappelen Damm Akademisk AS.

Røvik, K.A. (2007). Trender og translasjoner: ideer som former det 21. århundrets organisasjon. Oslo: Universitetsforlaget

Shields, R. \& Watermeyer, R. (2018). Competing institutional logics in universities in the United Kingdom: schism in the church of reason, Studies in Higher Education, DOI:

$\underline{10.1080 / 03075079.2018 .1504910}$ 
Schofer, E. \& Meyer, J.W. (2005). The Worldwide Expansion of Higher Education in the Twentieth Century. American Sociological Review, 70(6), 898-920.

Sursock, A. (2015). Trends 2015: Learning and teaching in European universities. EAU Publications. Retreived from https://www.researchgate.net/profile/Andree_Sursock/publication/279950904_Trends_2015_Learni ng_and_Teaching_in_European_Universities/links/559f6ac008ae03c44a5cf64a/Trends-2015Learning-and-Teaching-in-European-Universities.pdf?origin=publication_detail Stensaker, B., Maassen, P., Borgan, M., Oftebro, M. \& Karseth, B. (2007). Use, updating and integration of ICT in higher education: Linking purpose, people and pedagogy. Higher Education, (54), 417-433. DOI: http://dx.doi.org/10.1007/s10734-006-9004.

Sahlin, K. \& Wedlin, L. (2008). Circulating ideas: imitation, translation and editing. In R. Greenwood C. Oliver \& R. Suddaby The SAGE handbook of organizational. DOI:

\section{http://dx.doi.org/10.4135/9781849200387.n9}

Thornton, P.A. (2004). Markets from culture: Institutional logics and organizational decisions in higher education publishing, Stanford University Press

Tømte, C., Aanstad, S. \& Løver, N. (2016). Evaluering av eCampus-programmet. Oslo: NIFU.

Weick, K.E. (1976) Organizations as Loosely Coupled Systems. Administrative Science Quaterly. 21(1), $1-19$

Aagaard, T., Lund, A., Lanestedt, J., Ramberg, K. R. \& Swanberg, A., B. (2018). Sammenhenger mellom digitalisering og utdanningskvalitet - innspill og utspill. UNIPED 41 (3), 289-303

Aamodt, P. O.; Hovdhaugen, E., Stensaker, B., Frølich, N.; Maassen, P. \& Dalseng, C. F. (2016) Utdanningsledelse. En analyse av ledere av studieprogrammer i høyere utdanning. NIFU arbeidsnotat 2016:10. 